\title{
Plakophilin-2: a cell-cell adhesion plaque molecule of selective and fundamental importance in cardiac functions and tumor cell growth
}

\author{
Steffen Rickelt
}

Received: 7 December 2011 / Accepted: 16 December 2011 /Published online: 28 January 2012

(C) The Author(s) 2012. This article is published with open access at Springerlink.com

\begin{abstract}
Within the characteristic ensemble of desmosomal plaque proteins, the armadillo protein plakophilin-2 (Pkp2) is known as a particularly important regulatory component in the cytoplasmic plaques of various other cell-cell junctions, such as the composite junctions (areae compositae) of the myocardiac intercalated disks and in the variously-sized and -shaped complex junctions of permanent cell culture lines derived therefrom. In addition, Pkp2 has been detected in certain protein complexes in the nucleoplasm of diverse kinds of cells. Using a novel set of highly sensitive and specific antibodies, both kinds of Pkp2, the junctional plaque-bound and the nuclear ones, can also be localized to the cytoplasmic plaques of diverse non-desmosomal cellcell junction structures. These are not only the puncta adhaerentia and the fasciae adhaerentes connecting various types of highly proliferative non-epithelial cells growing in culture but also some very proliferative states of cardiac interstitial cells and cardiac myxomata, including tumors growing in situ as well as fetal stages of heart development and cultures of valvular interstitial cells. Possible functions and assembly mechanisms of such Pkp2-positive cell-cell junctions as well as medical consequences are discussed.
\end{abstract}

Keywords Adherens junctions · Myxomata $\cdot$ Cardiac tumors $\cdot$ Nuclear plakophilins $\cdot$ Plakophilin-2

\section{S. Rickelt $(\bowtie)$}

Helmholtz Group for Cell Biology,

German Cancer Research Center (DKFZ),

Im Neuenheimer Feld 581, Building TP4,

69120 Heidelberg, Germany

e-mail: s.rickelt@dkfz.de

S. Rickelt

Progen Biotechnik,

Heidelberg, Germany

\author{
List of abbreviations \\ $\mathrm{Ab}, \mathrm{mAb}$ Antibody, monoclonal antibody \\ AJ Adherens junction \\ ARVC/D Arrhythmogenic ventricular cardiomyopathy/ \\ dysplasia \\ As Antiserum \\ CJs Composite junctions \\ gp Guinea pig \\ IF Intermediate-sized filament \\ m Mouse \\ PBS Phosphate-buffered saline \\ Pkp Plakophilin \\ RT Room temperature
}

\section{Introduction}

Of the obligatory molecular ensemble components of desmosomes, the group of the plaque-bound plakophilins (Pkps), has been the last discovered. In vertebrate cells, this subfamily of the closely related members of the larger armadillo plaque protein family is represented by at least one of the three isoform proteins (Pkp1, Pkp2, Pkp3) in all desmosomes but desmosomes with two Pkps in nearequimolar amounts have also been described (for reviews, see, e.g., Bass-Zubek et al. 2009; Delva et al. 2010; Franke 2010; Godsel et al. 2004; Green et al. 2010; Hatzfeld 2007; Neuber et al. 2010; Schmidt and Jaeger 2005; Schmidt and Koch 2008; Schmidt et al. 1994). Pkp2 shows the most widespread occurrence in the desmosomes of all proliferative epithelial cells of normal tissues as well as of the tumors and of cell cultures derived therefrom, in meningiothelia and meningiomas (Akat et al. 2003, 2008) and in the composite junctions connecting cardiomyocytes (Borrmann et al. 2000, 
2006; Franke et al. 2006; Mertens et al. 1996, 1999). Pkp3 coexists in similar amounts in the desmosomes of many of these cell types, with the exception of, e.g., hepatocytes and cardiomyocytes (Bonné et al. 1999, 2003; Borrmann et al. 2000, 2006; Rickelt et al. 2009, 2010; Schmidt et al. 1999; for tumors, see, e.g., Furukawa et al. 2005; Kundu et al. 2008; for special negative effects on Pkp3, see Aigner et al. 2007).

By contrast, Pkp1 has been found in suprabasal, highly differentiated cell layers of stratified epithelia (Hatzfeld et al. 1994; Moll et al. 1997; Schaefer et al. 1993; Schmidt et al. 1994; reviews: Bass-Zubek et al. 2009; Neuber et al. 2010; Schmidt and Koch 2008) and has also been noted in certain types of cells of stratified squamous carcinomas (for references, see, e.g., Franke 2010; Mertens et al. 1999; Neuber et al. 2010; Papagerakis et al. 2003; Schwarz et al. 2006; Sobolik-Delmaire et al. 2007; South et al. 2003). For two of the Pkps, two prominent splice variants of the gene products have been determined (Hatzfeld et al. 1994; Heid et al. 1994; Mertens et al. 1996; Schmidt et al. 1994; see also Gandjbakhch et al. 2011). Finally and rather surprisingly, diffusible nuclear and cytoplasmic forms, including some rather stable functional complexes, have also been described for all three Pkps (e.g., Bass-Zubek et al. 2008; Bonné et al. 1999; Hofmann et al. 2006; Mertens et al. 1996, 2001; Mueller et al. 2003; Schmidt et al. 1997). Table 1 summarizes the molecular data of the presently known human Pkp splice variant forms and the chromosomal position of the three genes.

Antibodies (Abs) specific for cytoskeletal molecules and thus characteristic of certain cell types have become important in the development and refinement of cell type diagnoses of tumors, in particular metastases (for references, see, e.g., Folpe and Gown 2001; Franke et al. 1983; Garrod et al. 1996; Gown and Vogel 1984; Mertens et al. 1999; Miettinen 2003; Moll 1993; Moll et al. 1986; Parrish et al. 1986). However, in the field of molecular diagnoses of most nonepithelial tumors, including those located in or at the heart as well as those derived from heart tissues, the progress made so far is still rather modest. Thus, it is hoped that

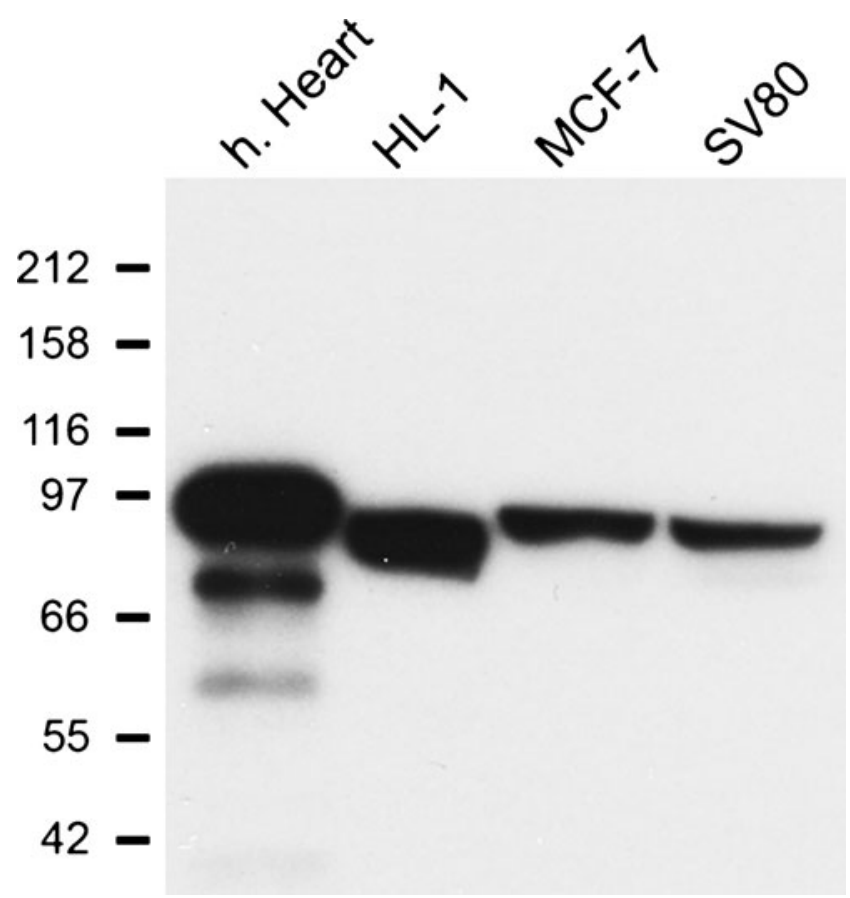

Fig. 1 Immunoblot specificity of the plakophilin-2 (Pkp2) antibodies used on polypeptides of total protein lysates of various mammalian cell cultures and human heart tissue. Immunoblot reaction of monoclonal murine antibodies (mAbs) specific for Pkp2 on SDS-PAGE-separated polypeptides present in lysates of cryostat sections of human heart tissue (h. Heart) (lane 1) or in lysates of permanently growing adult mouse cardiomyocyte-derived cells of line $H L-1$ (lane 2), cells of the human breast adenocarcinoma-derived line MCF-7 (lane 3) or SV40virus transformed human fibroblasts of line SV80 (lane 4). Note that the single polypeptide band of ca. $97 \mathrm{kDa}$ appears not only in lysates of myocardial tissue and cardiomyocyte-derived cells but also of the epithelium-derived cells and in the transformed SV80 fibroblasts. Positions of polypeptide molecular weights are indicated on the left and correspond to 212,158,116, 97, 66, 55 and $42 \mathrm{kDa}$ (from top to bottom)

new analytical insights into the cell type-specific components of the various cardiac cells will also contribute to the advancement of molecular diagnostics of cardiac tumors (for references, see McAllister and Fenoglio 1978; Miettinen 2003; Rickelt et al. 2010; Sheppard 2011).

Table 1 Molecular and biochemical characteristics of the presently characterized five prominent human plakophilin splice variant forms and the chromosomal position of the three genes

\begin{tabular}{lllllllll}
\hline & $\begin{array}{l}\text { Splice } \\
\text { VarianTs }\end{array}$ & Accession number & $\begin{array}{l}\text { Chromosome } \\
\text { localization }\end{array}$ & $\begin{array}{l}\text { Size of } \\
\text { mRNA (bp) }\end{array}$ & $\begin{array}{l}\text { No. of amino } \\
\text { acids }\end{array}$ & $\begin{array}{l}\text { Mol. wt } \\
\text { (calc.) }\end{array}$ & $\begin{array}{l}\text { Isoelectric } \\
\text { point (calc.) }\end{array}$ & $\begin{array}{l}\text { No. of arm-repeat units } \\
\text { Plakophilin-1 }\end{array}$ \\
& Pkp1a & NM_000299.3 & $1 \mathrm{q} 32$ & 5,384 & 726 & 80,496 & 9.18 & 9 \\
Plakophilin-2 & Pkp1b & NM_001005337.2 & & 5,447 & 747 & 82,860 & 9.29 & 9 \\
& Pkp2b & NM_001005242 & 12p11 a & 4,307 & 837 & 92,756 & 9.35 & 9 \\
Plakophilin-3 & Pkp3 & NM_004572 & & 4,439 & 881 & 97,415 & 9.39 & 9 \\
\hline
\end{tabular}

${ }^{\mathrm{a}}$ For Pkp2, a pseudogen at chromosome 12p13 has also been characterized (Bonné et al. 2000). 


\section{Materials and methods}

Tissues and cell cultures

Samples from human heart tissue were obtained from the Department of Cardiac Surgery of the University Hospital Heidelberg, Germany (for details, see also Barth et al. 2009). Bovine as well as rat and mouse tissue samples, including fetal tissues, were freshly obtained from the regional slaughterhouse (Mannheim) or the laboratory animal facilities of the German Cancer Research Center (Heidelberg) as described (e.g., Franke et al. 2006). In addition, skin and heart tissue specimens from fetal German landrace pigs were provided from the Institute of Farm Animal Genetics (Friedrich-Loeffler-Institute, Mariensee, Germany). In general, the samples were fixed either with $4 \%$ formaldehyde in phosphate-buffered saline (PBS) and embedded in paraffin or snap-frozen in isopentane that had been precooled in liquid nitrogen and then stored at $-80^{\circ} \mathrm{C}$ until use.

For the present study, cell cultures of the adult mouse cardiomyocyte-derived line HL-1 as well as various human cell lines, including breast adenocarcinoma-derived line MCF-7, HaCaT keratinocytes, diploid lung fibroblasts of line WI38, SV40-virus transformed WI38 fibroblasts (line WI38VA13, subline 2RA) and SV40-virus transformed fibroblasts of line "SV80" were kept and used as described (e.g., Barth 2011; Barth et al. 2009; Claycomb et al. 1998; Pieperhoff et al. 2011; Rickelt et al. 2009). For comparison, bovine dermal fibroblasts of line B1, mouse 3T3 embryonic mesenchymal cells and the "junctionlacking" murine fibroblasts of strain L929 were examined in parallel.

\section{Antibodies}

The murine monoclonal antibodies (mabs) and polyclonal guinea pig Abs specific for plakophilins (Pkps) used in this study are listed below. Further Abs for immunofluorescence microscopy and immunoblotting analyses of gel-electrophoretically-separated polypeptides against adhering junction (AJ) proteins and glycoproteins as well as diverse cytoskeletal and nuclear proteins have been described elsewhere (e.g., Barth et al.
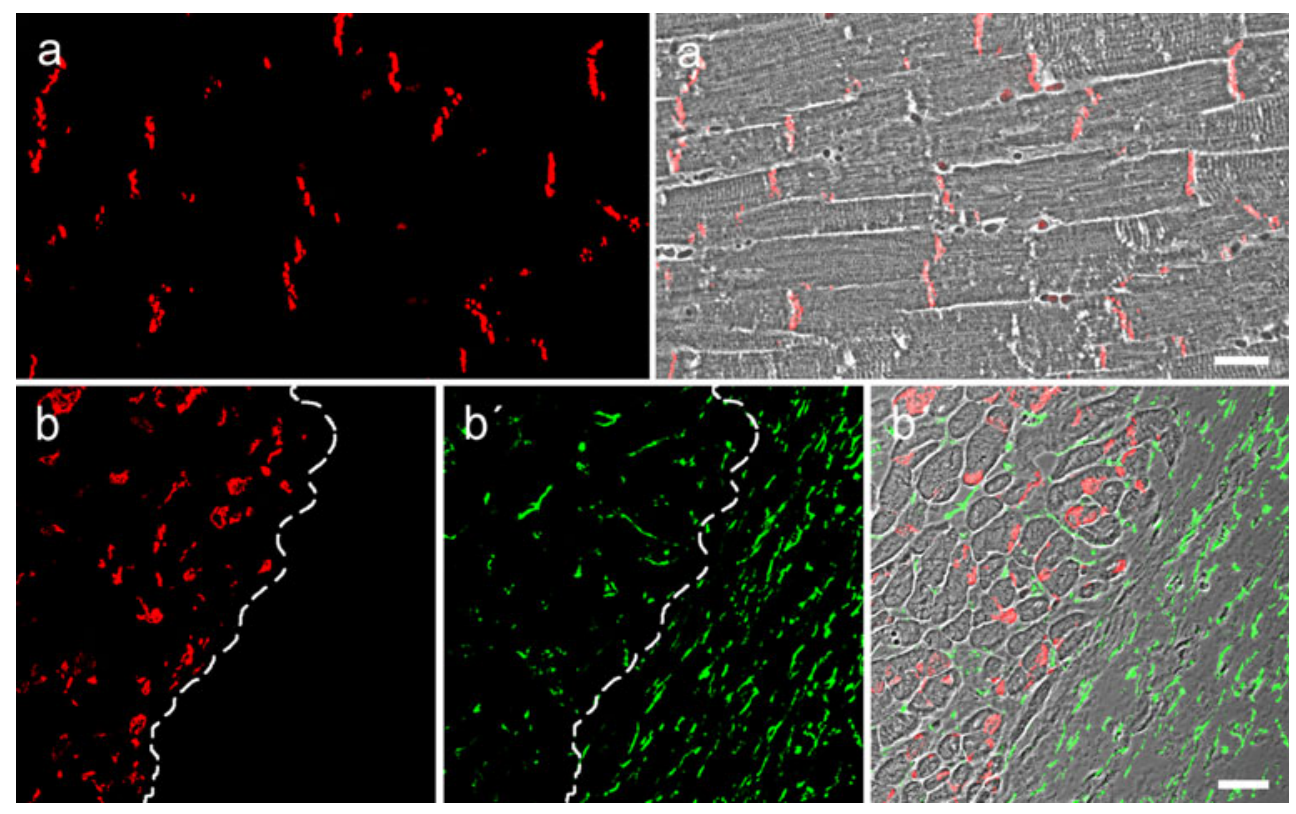

Fig. 2 Immunolocalization of plakophilin-2 (Pkp2) in mammalian heart tissues. Double-label, confocal-laser scanning immunofluorescence microscopy of sections through formaldehyde-fixed and paraffin-embedded human myocardium $\left(\mathbf{a}, \mathbf{a}^{\prime}\right)$ or through the border region between a pulmonary valve and the myocardium of an ovine heart (b-b"), after antigen-retrieval treatment and reaction with mAbs specific for Pkp2 (red; a, $\mathbf{a}^{\prime}, \mathbf{b}, \mathbf{b}^{\prime \prime}$ ) and polyclonal antibodies (Abs) against the intermediate-sized filament (IF) protein vimentin (green; $\mathbf{b}^{\prime}$, $\left.\mathbf{b}^{\prime \prime}\right)$. Note the positive immunostaining of $\mathrm{Pkp} 2$ in the composite junctions (areae compositae) of the myocardial intercalated disks ( $\mathrm{red} ; \mathbf{a}, \mathbf{a}^{\prime}$ and in $\mathbf{b}$ the region on the left hand side of the dashed line) and its absence in the cell-cell contacts between the valvular interstitial cells (VICs) in the heart valve $\left(\mathbf{b}^{\prime}, \mathbf{b}^{\prime \prime}\right.$; region on the right hand side of the dashed line). Note the widespread occurrence of vimentin-positive VICs, including the myocardiac interstitial cells ( $\mathbf{b}^{\prime}$; green-stained cells left from the dashed line). The corresponding merged pictures $\left(\mathbf{a}^{\prime}, \mathbf{b}^{\prime \prime}\right)$ are shown on a phase contrast background to allow a clear distinction of myocardial tissue (b"; left) and interstitial cells of the valve (b"; right). Figures b-b" were kindly provided by Dr. Mareike Barth (present address: Institute for Pharmacology and Clinical Pharmacology / Department of Cardiovascular Surgery-Experimental Surgery, University Hospital Duesseldorf, Duesseldorf, Germany). Scale bars $20 \mu \mathrm{m}$ 
2009; Franke and Rickelt 2011; Rickelt et al. 2009, 2011a; Wuchter et al. 2007).

\begin{tabular}{lll}
\hline Antigen & Antibody type & Reference \\
\hline Plakophilin-1 & a) mAb, m (PP1-5C2) & Heid et al. 1994 \\
& b) As, gp (GP-PP1) & Heid et al. 1994 \\
Plakophilin-2 & a) mAb, m (Pkp2-518) & Rickelt et al. 2010 \\
& b) mAb, m (PP2/62, PP2/86, & Mertens et al. 1996 \\
& PP2/150) & Rickelt et al. 2010 \\
Plakophilin-3 & a) mAb, m (PKP3-270) & Schmidt et al. 1999 \\
& b) As, gp (GP-PP3-1) & Schmidt et al. 1999 \\
\hline
\end{tabular}

All Abs mentioned were obtained from Progen Biotechnik (Heidelberg). Antigen-bound primary Abs were visualized with secondary Abs coupled to Cy3 (Dianova, Hamburg, Germany) or Alexa 488 (MoBiTec, Goettingen, Germany). 4',6-Diamidino-2-phenylindol (DAPI; Serva, Heidelberg) was applied for staining nuclei (see, e.g., Pieperhoff et al.
2008). For immunoblot analysis, horseradish peroxidaseconjugated secondary Abs were applied (Dianova).

\section{Immunofluorescence microscopy}

Methods for immunofluorescence microscopy were essentially as described for cardiac tissues and cultured cardiomyocytes or interstitial cells in —or from - heart valves (Barth 2011; Barth et al. 2009; Franke et al. 2006; Pieperhoff and Franke 2007; Pieperhoff et al. 2008, 2011; Rickelt 2010; Rickelt et al. 2009, 2010, 2011a).

For the dual - junctional and nuclear - staining of the Pkps on sections through frozen tissues and on monolayers of cultured cells, several procedures were developed (see also previous reports, such as Mertens et al. 1996, 1999; Pieperhoff et al. 2011; Rickelt et al. 2010; Schmidt et al. 1997). Therefore, the cultured cells grown on poly-(L)-lysine-coated coverslips were briefly rinsed with PBS containing $2 \mathrm{mM} \mathrm{MgCl}_{2}$ and fixed at $-20^{\circ} \mathrm{C}$ in methanol $(5 \mathrm{~min})$ and acetone $(30 \mathrm{~s})$. The frozen tissue sections were mounted on coverslips, airdried, and fixed for $10 \mathrm{~min}$ in $-20^{\circ} \mathrm{C}$ acetone. The cell or
Fig. 3 Localization of plakophilin-2 (Pkp2) in nuclei and desmosomes of cultured human breast adenocarcinomaderived cells of line MCF-7. Double-label, confocal-laser scanning immunofluorescence microscopy showing Pkp2 (green) in a small colony of four MCF-7 cells, using polyclonal guinea pig Abs in comparison with the reactions of Abs against keratin IFs (red; murine mAb Lu-5). Note the specific staining of Pkp2 in the typical punctate arrays of desmosomal junctions and the dot-like exo- or endocytotic vesicles associated with desmosomal molecules in the cytoplasm, whereas the cell-cell junction free surface regions are negative. Note in addition the granular fluorescence staining of Pkp2 in the nucleus whereas the nucleoli are negative. Scale bar $20 \mu \mathrm{m}$

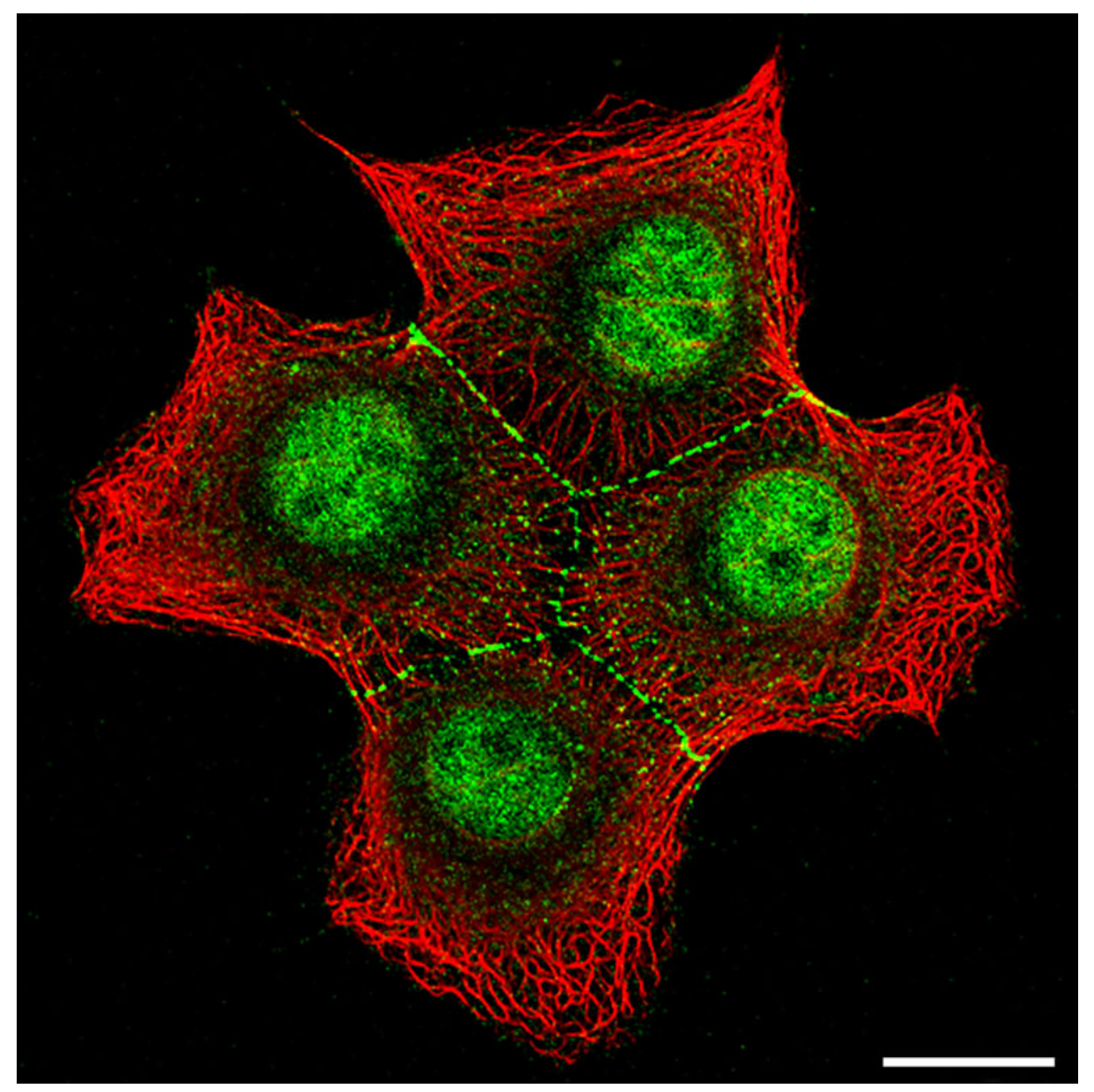


tissue specimens were rehydrated before incubation with the primary Abs according to one of the following protocols:

(1) For junctional localization, the specimens were permeabilized in PBS containing $0.2 \%$ Triton X-100 for $5 \mathrm{~min}$, rinsed for $5 \mathrm{~min}$ with $\mathrm{PBS}$ and then treated with the primary Abs for $1 \mathrm{~h}$ at room temperature (RT), followed by 3 washes with PBS ( 5 min each) and incubation with the appropriate secondary Abs (45 min, RT).

(2) For nuclear staining, the cultured cells or the tissue sections were briefly rinsed with PBS and the primary and secondary Abs were applied for 20 or $30 \mathrm{~min}$ each, with three 2-3 min PBS washes between each incubation.

(3) For optimal dual-localization, the cells were fixed for 5 min in $2 \%$ formaldehyde in PBS, freshly made from paraformaldehyde, followed by a brief rinse in distilled water, 5 min quenching in $50 \mathrm{mM} \mathrm{NH}_{4} \mathrm{Cl}$ in $\mathrm{PBS}$, another PBS wash and incubation in PBS containing $0.2 \%$ Triton $\mathrm{X}-100$ for 5-20 $\mathrm{min}$, before exposure to primary and secondary Abs according to (1).

After the binding of the secondary Abs, the specimens were generally washed again thrice with PBS, briefly rinsed with distilled water and finally dehydrated in absolute ethanol for $1 \mathrm{~min}$. After air-drying, the specimens were mounted with Fluoromount-G (Southern Biotech; obtained through Biozol Diagnostica, Eching, Germany). Finally, immunofluorescence microscopic images were recorded with an Axiophot II photomicroscope (Carl Zeiss, Jena, Germany), equipped with an AxioCam HR (Carl Zeiss). For confocal laser scanning microscopy a Zeiss LSM 510 Meta microscope was used.

For immunolocalizations on paraffin-embedded tissue samples, the sections were deparaffinized and subjected to antigen-retrieval treatment according to standard protocols (see the anthology of Shi et al. 2000; for specific details, see also Rickelt et al. 2010).

\section{Gel electrophoresis and immunoblotting}

Tissue samples and cultured cells were analyzed by SDSPAGE, followed by immunoblotting, as described (Barth 2011; Borrmann et al. 2006; Rickelt 2010; Rickelt et al. 2009, 2010).

\section{Results}

Properties of new Pkp2-specific antibodies

As the two major isoforms of Pkp2 (Table 1) based on alternative splicing of the primary gene products and termed
Pkp2a and Pkp2b (Christensen et al. 2010b; Gandjbakhch et al. 2011; Mertens et al. 1996, 1999; Schmidt and Jaeger 2005; Watkins et al. 2009) might differ in their local detectability with immunocytochemical methods and might be located in different positions, I generated antibodies (Abs) of high specificity and affinity allowing reliable Pkp2reactions on sections through formaldehyde-fixed, paraffin-embedded tissue samples as well as on cultured cells (see also Schmidt et al. 1997). The monoclonal and
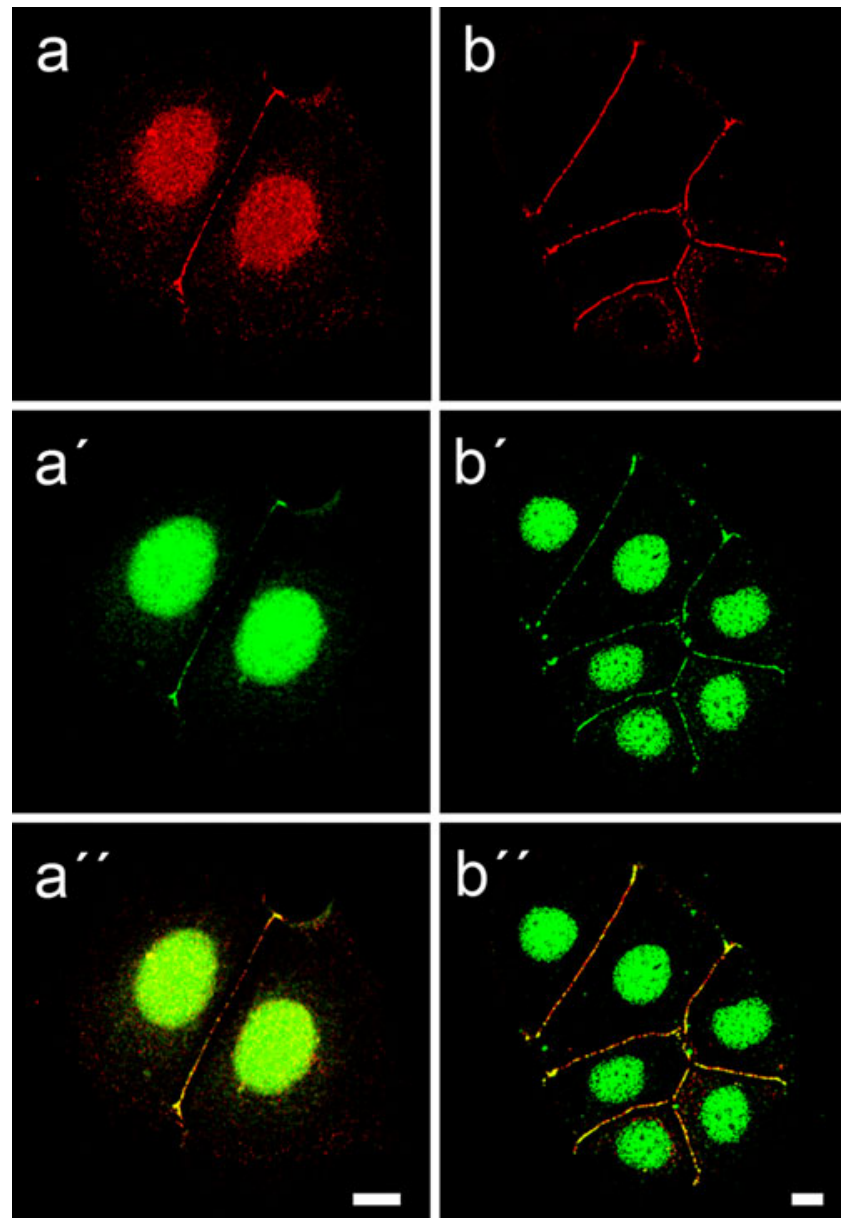

Fig. 4 Specific dual localization of plakophilin-2 (Pkp2) in nuclei and desmosomes of cultured human breast adenocarcinoma-derived MCF7 cells. a-a" Confocal laser-scanning immunofluorescence microscopy of a double-label experiment, comparing the reactions of two Abs against different epitopes of Pkp2 (a, red: mAb Pkp2, clone Pkp2-518; $\mathbf{a}^{\prime}$, green: guinea pig Abs of serum GP-PP2) in two adjacent MCF-7 cells. The corresponding merged picture (a") shows the colocalization of both kinds of Pkp2 Abs (yellow merged color) in desmosomes at cell-cell borders and in small granules in the nucleus. b-b" Doublelabel immunolocalization micrographs of small colonies of MCF-7 cells, showing the frequent colocalization of Pkp2 ( $\mathbf{b}^{\prime}, \mathbf{b}^{\prime \prime}$; green) with the desmosomal plaque protein desmoplakin $\left(\mathbf{b}, \mathbf{b}^{\prime \prime} ;\right.$ red $)$. Note also the intense reaction of $\mathrm{Pkp} 2$ in the nucleus, in contrast to the absence of desmoplakin, while both proteins colocalize ( $\mathbf{b}^{\prime \prime}$, yellow merged color) in most-but not all-desmosomes in the cell-cell contact regions. Scale bars $10 \mu \mathrm{m}$ 
polyclonal Abs selected gave essentially similar results with immunoblotting of SDS-PAGE-separated polypeptides of normal and tumor tissue samples, including vertebrate heart tissue and cell cultures (Figs. 1 and 2). Remarkably, all these Pkp2 Abs also revealed the Pkp2 present in the neuroendocrine ("Merkel") cell half of the hybrid (heterotypic) desmosomes as recently demonstrated (Rickelt et al. 2011a). And, finally, the new Abs reacted rather broadly with the nuclear Pkp2 forms, showing a generally granular nucleoplasmic appearance and leaving the nucleoli negative (Figs. 3, 4, 5 and 7), as well as with cell-cell junctions of diverse desmosome-free cell cultures (Figs. 4, 6 and 7).

Pkp2 reactions on non-epithelial, non-cardiomyocytic cells

The Pkp2-positive reactions also revealed nuclear structures in cultured cells known to be totally devoid of desmosomes and any other adherens junctions (AJs; e.g., Fig. $7 \mathrm{c}-\mathrm{c}^{\prime \prime}$ ). Furthermore, using unmasking immunostaining conditions (e.g., procedure 3 of "Materials and methods") it was possible to detect and localize two major Pkp2 forms simultaneously, one in small nucleoplasmic granules (Fig. 7a, b) and the other in non-desmosomal AJs of the puncta adhaerentia or fasciae adhaerentes types (Figs. 6a-c and 7a, b). Simultaneously, i.e. in the same cells and under the same immunocytochemical conditions, it could also be demonstrated that such non-desmosomal cell-cell AJs immunostained for Pkp2 were also positive for $\mathrm{N}$-Cadherin, $\alpha$ - and $\beta$-catenin (Fig. 6a-c) as well as for cadherin-11 and for the armadillo proteins plakoglobin, p120 and p0071 (not shown here; see also Rickelt et al. 2009).

At present, it cannot be explained why certain cell lines derived from different species and tissues synthesize remarkable amounts of Pkp2 (Fig. 8), whereas others, including some directly related to each other, are negative (compare, e.g., lines WI38 and WI38VA13 in Fig. 8; see also Rickelt et al. 2009).

Fig. 5 Nuclear localization of plakopilin-2 (Pkp2) in fetal porcine snout epithelium. a, b Immunofluorescence microscopy showing the localization of polyclonal guinea pig Abs specific for Pkp2 (red) on cryostat sections through fetal porcine snout epithelium in comparison with the desmosomal plaque protein desmoplakin (green). Under these immunostaining conditions used here the intense and specific nuclear localization of Pkp2 (red) contrasts with the desmoplakin immunostaining restricted to the desmosomes of all keratinocytes. Note also the absence of both the uppermost layers of the stratum corneum (b, bracket; the tissue surface is denoted by the arrowheads). The picture of (b) is presented on a phase contrast background. Note in addition that Pkp2 is - in addition to the nuclei-also specifically located in distinct "dot-like" structures in the basal cell layer, representing one half of the heterotypic desmosomes connecting the keratinocytes and the neuroendocrine "Merkel cells" (insert in b shows a magnification of one of the Merkel cells in the basal layer in the right lower corner). Scale bar $20 \mu \mathrm{m}$
Cardiac myxomata

When the more sensitive new Abs were examined on diverse non-epithelium-derived cell culture types and tissues, it soon became obvious that the cells of many non-carcinomatous
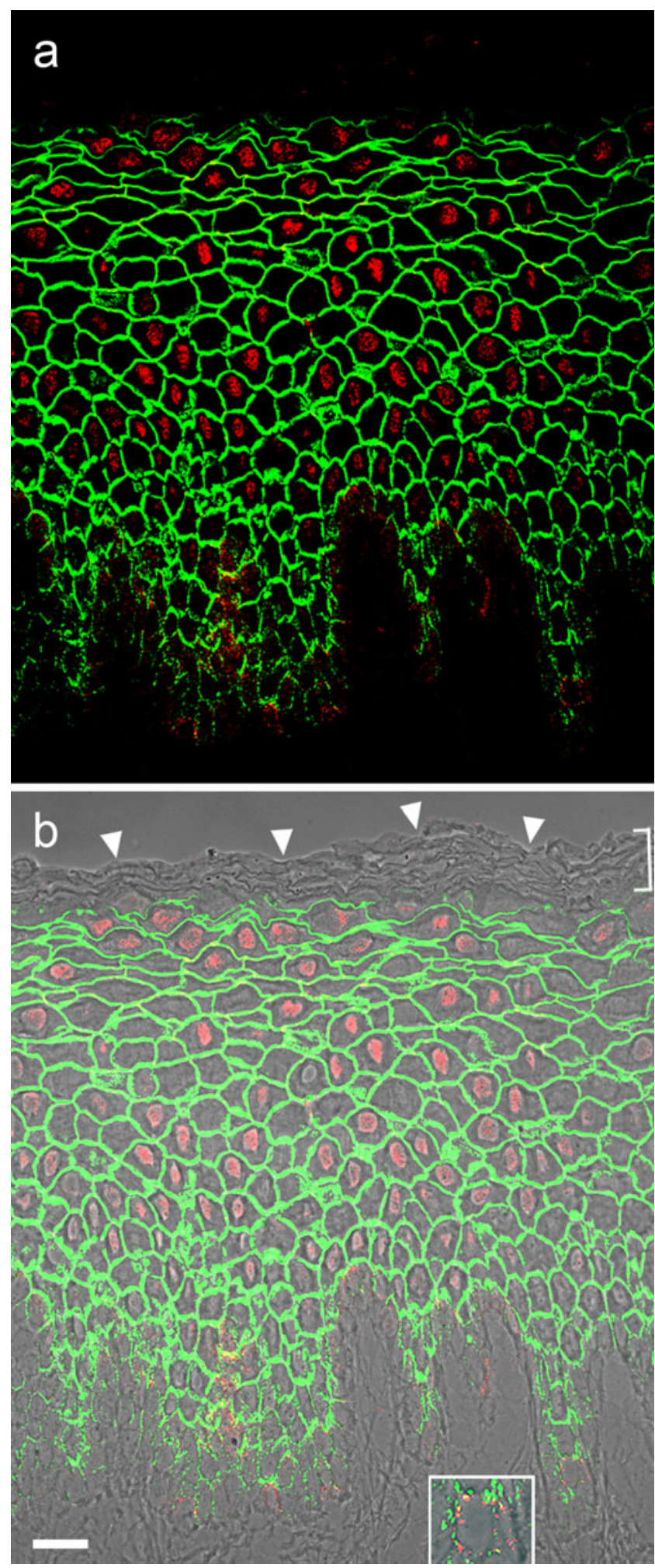

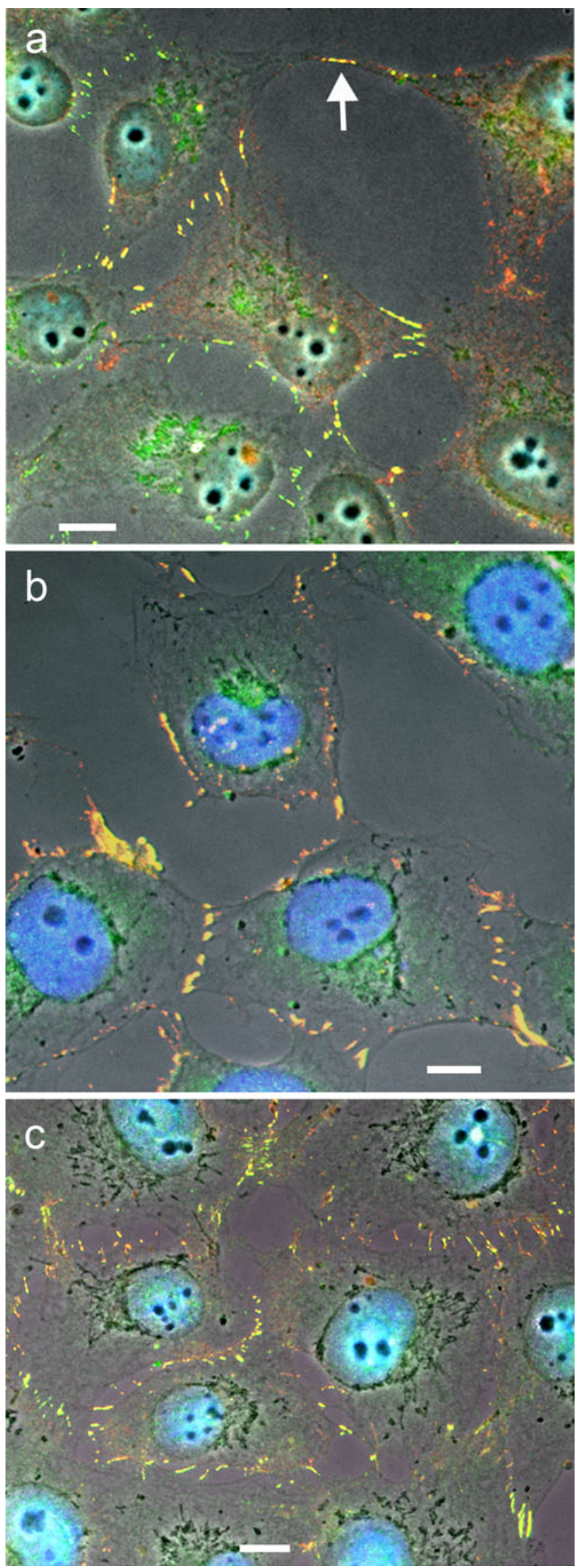

Fig. 6 Identification and localization of plakophilin-2 (Pkp2) in adherens junctions (AJs) of highly proliferating cultured human fibroblasts. Double-label immunofluorescence microscopy images of SV40transformed human fibroblasts (line SV80), after reaction with Abs to Pkp2 (a, red; murine mAbs, or $\mathbf{b}$ and $\mathbf{c}$, green: guinea pig Abs), in comparison with constitutive $\mathrm{AJ}$ proteins such as the transmembrane glycoprotein N-cadherin (a, green: polyclonal rabbit Abs) and the (redlabeled) murine $\mathrm{mAbs}$ specific for the cytoplasmic AJ plaque proteins $\alpha-(b)$ and $\beta$-catenin (c). Note that both kinds of Pkp2 Abs clearly colocalize with the AJ proteins (yellow merged color) not only when grown at low density $(\mathbf{a}, \mathbf{b})$ but also near confluency (c). In addition, such colocalization can also be seen in small cell-cell junctions connecting slender cell processes (see, e.g., arrow in a). DAPI staining (blue) was used to visualize the nuclei. Scale bars $10 \mu \mathrm{m}$
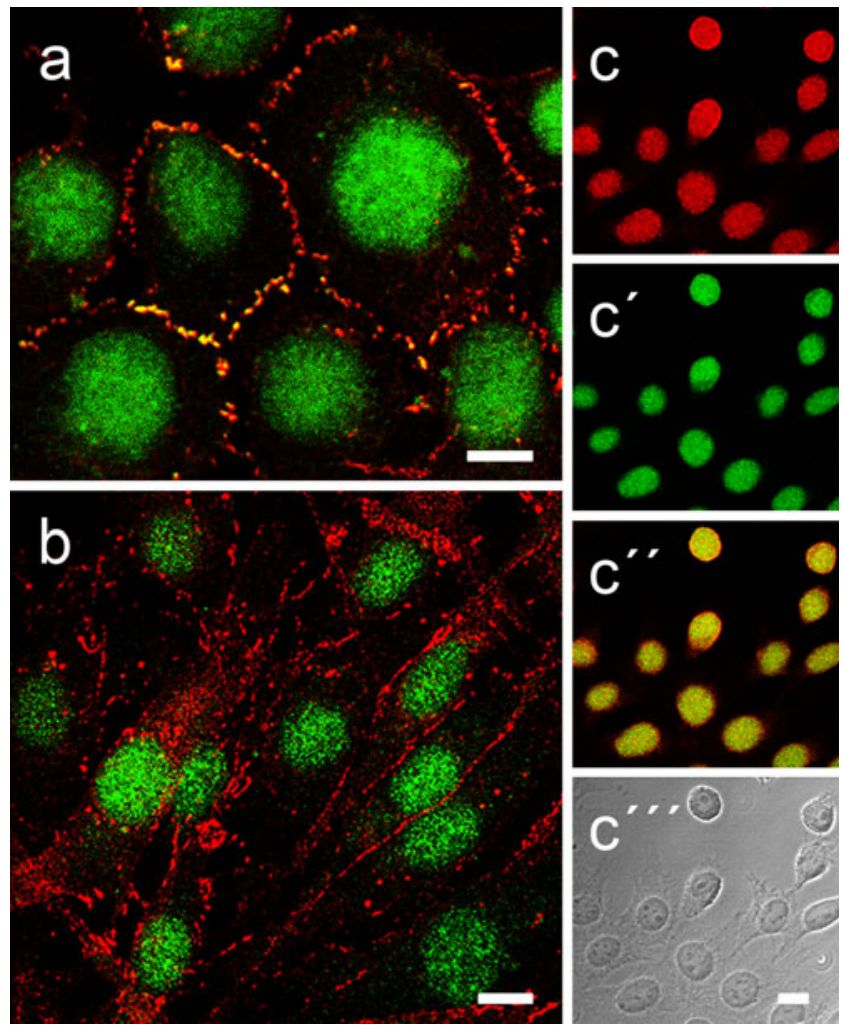

Fig. 7 Differential localization of plakophilin-2 (Pkp2) in mammalian fibroblasts. Double-label, laser-scanning immunofluorescence microscopy of cultured transformed human fibroblasts of line SV80 (a), bovine dermal fibroblasts of line B1 (b) and mouse fibroblasts of strain L929 after formaldehyde fixation and detergent-treatment (for details, see "Materials and methods"). Here, the immunolocalization of polyclonal guinea pig Abs specific for Pkp2 (a, b, $\mathbf{c}^{\prime}, \mathbf{c}^{\prime \prime}$; green) and the adherens junction (AJ) proteins $\mathrm{N}$-cadherin $(\mathbf{a}, \mathbf{b} ;$ red $)$ and $\beta$-catenin $\left(\mathbf{c}, \mathbf{c}^{\prime \prime} ; \mathrm{red}\right)$ is shown. Under these conditions, both the specific staining of junctions at the cell-cell boundaries and the intense nuclear staining are seen. Note, however, that in the transformed fibroblasts (a), Pkp2 occurs in the N-cadherin-positive AJs (yellow merged color) whereas AJs of untransformed B1 fibroblasts lack Pkp2. In all fibroblasts, Pkp2 is also abundant in the nucleus (a-c) in comparable amounts as $\beta$ catenin as shown in the "junction-lacking" L929 fibroblasts $(\mathbf{c}-\mathbf{c}$ "). The corresponding merged color picture $\left(\mathbf{c}^{\prime \prime}\right)$ and the phase contrast background ( $\left.\mathbf{c}^{\prime \prime \prime}\right)$ images are presented in addition in order to see the cytoplasms of these cells. Scale bars $10 \mu \mathrm{m}$ 


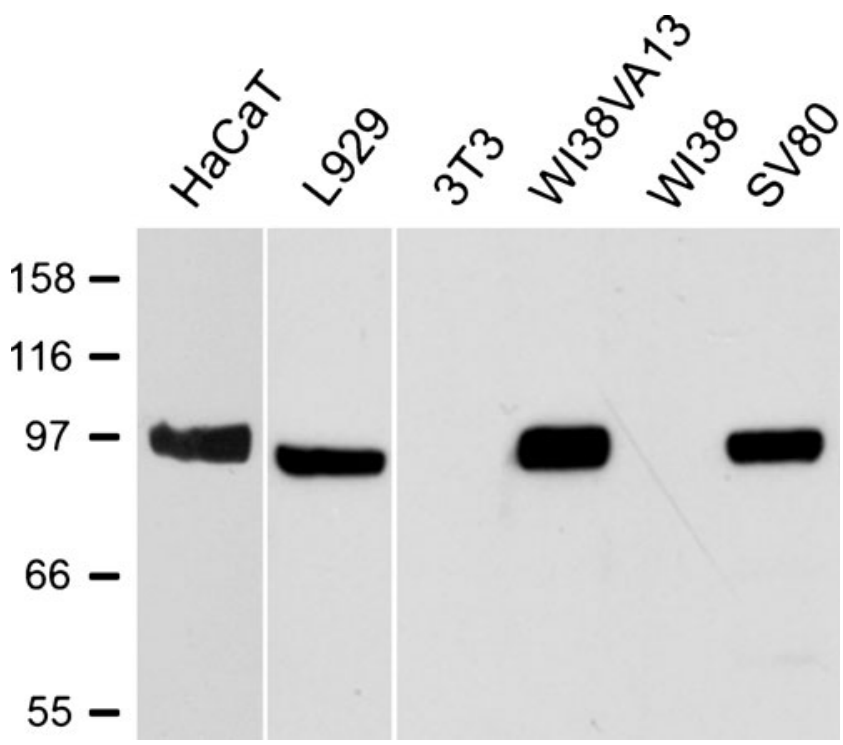

Fig. 8 Immunoblot specificity of plakophilin-2 (Pkp2) on polypeptides of total protein lysates of murine and human fibroblastoidal cells. Immunoblot reaction of murine mAbs specific for Pkp2 on SDSPAGE-separated polypeptides presents in lysates of permanently growing human keratinocytes of line $\mathrm{HaCaT}$ (lane 1), murine fibroblasts of lines L929 (lane 2) and 3 T3 (lane 3), SV40-virus transformed (line WI38VA13; lane 4) and non-transformed (lane 5) human diploid lung fibroblasts of line WI38 and SV40-virus transformed human fibroblasts of line SV80 (lane 6). Note that the Pkp2-specific polypeptide band of ca. $97 \mathrm{kDa}$ appears not only in lysates of HaCaT keratinocytes and transformed fibroblasts (WI38VA13 and SV80) but also in the "junction-lacking" L929 fibroblasts. Positions of polypeptide molecular weights are indicated on the left and correspond to $158,116,97,66$ and $55 \mathrm{kDa}$ (from top to bottom)

tumor cells were connected by non-desmosomal cell-cell junctions containing cadherin-11, N-cadherin, $\alpha$ - and $\beta$ catenin and plakoglobin as well as proteins p120 and p0071 (e.g., Rickelt et al. 2009, 2010). Such cells included in particular one group of cardiac tumors, the "cardiac myxomata", the nucleus-containing cell bodies of which were for the most part distant from each other and separated by extracellular matrix

Fig. 9 Localization of plakophilin-2 (Pkp2) in adherens junctions (AJs) of human cardiac myxomata. Laser-scanning, double-label immunofluorescence microscopy of sections through formaldehyde-fixed and paraffin-embedded human myxomata, treated for antigen-retrieval and double-immunostained with mAbs to Pkp2 (red), in comparison with green-labeled polyclonal Abs decorating IF bundles of the vimentin-type (a-c), the vascular endothelial transmembrane glycoprotein VE-cadherin (d) and the cell proliferation marker protein Ki67 (e). Note the extensive localization of Pkp2 in the AJs connecting myxoma cell processes, which also contain vimentin IFs $(\mathbf{a}-\mathbf{c})$. b, c Higher magnification micrographs of the region shown in (a), demonstrating that Pkp2-positive puncta adhaerentia are often clustered and appear as "beaded chains". d Note here that the AJs connecting the endothelial cells of vessels $(V)$, which are recognized by their intense VE-cadherin staining, are negative for Pkp2. Moreover, in myxomata, only a few cells undergo cell division as seen by immunostaining with $\mathrm{Ki} 67$ as proliferation marker (e). DAPI staining (blue) was used to visualize the nuclei in (d). $V$ vessel lumen. Scale bars $10 \mu \mathrm{m}(\mathbf{b}, \mathbf{c}), 20 \mu \mathrm{m}(\mathbf{a}, \mathbf{d}, \mathbf{e})$ structures (e.g., Fig. 9a), as is typical for such tumors (for references, see McAllister and Fenoglio 1978; Sheppard 2011; Travis et al. 2004). These frequent and mostly rather long cell processes often showed cell-cell contacts with an AJ morphology, which by electron microscopy (e.g., Rickelt et al. 2010) as well as in their molecular composition were negative for all desmosome-type components but strongly positive for Pkp2 colocalizing with the various non-desmosomal junction molecules mentioned (Fig. 9a-d; b and c show partial magnifications of $\mathrm{AJ}$ clusters at small contact sites between two tumor cells). As these cells were all positive for the IF protein
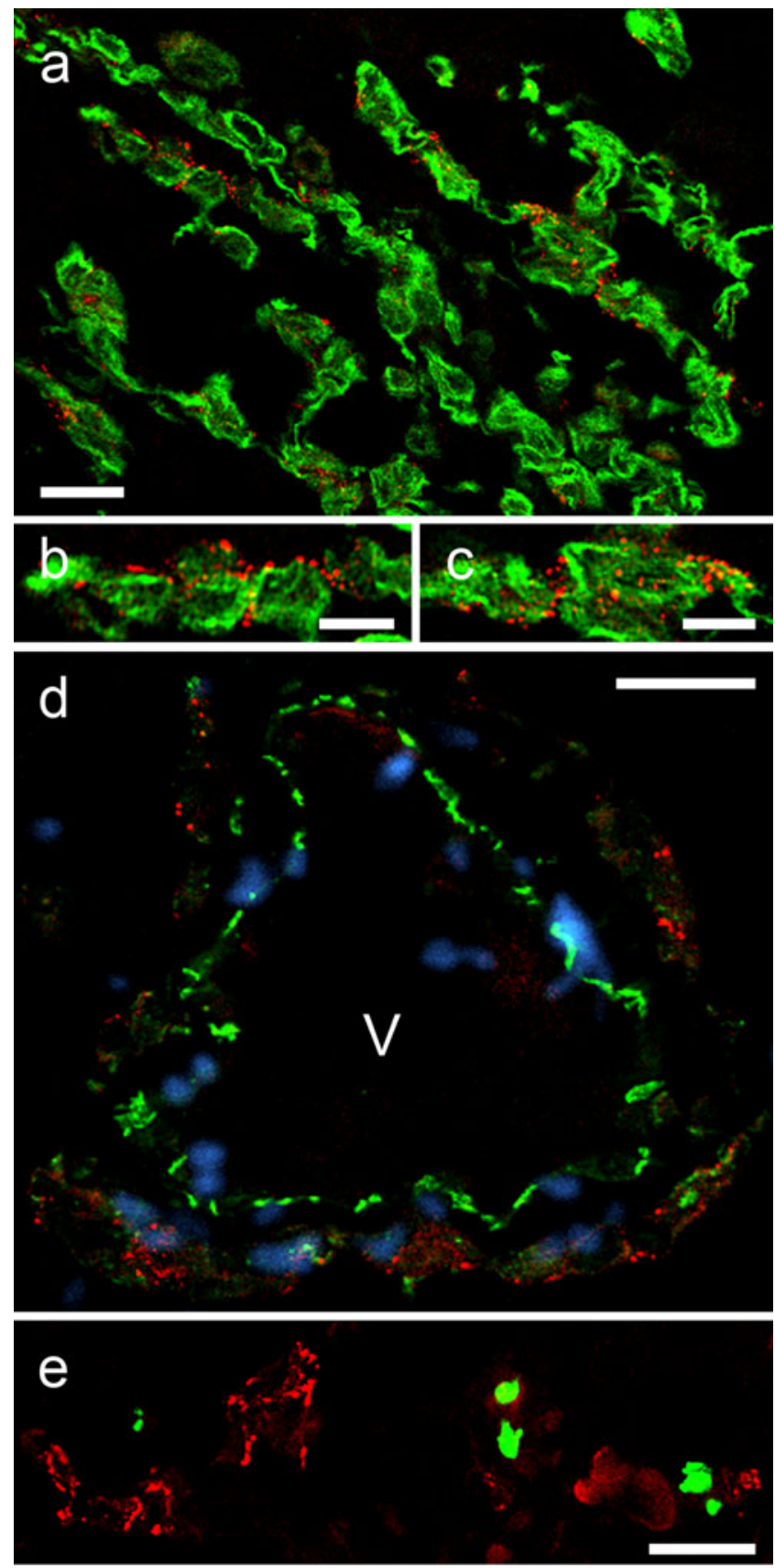
vimentin and negative for keratins, desmin and the typical epithelial junction marker proteins, desmoglein Dsg2, desmocollin Dsc2 and desmoplakin and also for $\alpha$-cardiac actin and the myocardiac variants of troponin and myosin (for applications of myocardiac markers in tumor diagnoses, see, e.g., Moll et al. 2006), any relationship to carcinomatous or myocardiumderived tumors appeared to be excluded. Moreover, as indicated by the absence of VE-cadherin reactions (e.g., Fig. 9d) and factor VIII-related antigen (not shown), any derivation of these tumor cells from vascular endothelial cells was also excluded (for the rather modest positivity with the nuclear proliferation index protein Ki57 see Fig. 9e).

\section{Discussion}

The special importance of plakophilin-2 (Pkp2) in the formation and architectonic organization of the desmosomal junctions as well as of other, more complex, junctions such as the composite junctions (CJs) of the myocardial intercalated disks has first been directly demonstrated by the successive cumulative transfection experiments of Koeser et al. (2003) and most impressively in the gene knock-out experiments of Grossmann et al. (2004; for special details, see also Grossmann 2005). In addition, immunoelectron microscopic localization studies have shown that at least a portion of Pkp2 is positioned very close to the desmosomal or CJ membrane (Borrmann 2000; Franke et al. 2006; Mertens et al. 1996; for the "molecular location maps" of other Pkps, see also North et al. 1999; Bass-Zubek et al. 2009). Certainly, the most eyeopening experimental results in this respect were the observations of Grossmann et al. (2004) that, in the forming embryonic heart, the normal architectonic order of the assembly of the cardiac structural elements was lost in the absence of Pkp2, so that a large portion of desmoplakin, the major plaque protein, appeared in non-ordered aggregates dispersed over the cytoplasm far away from the plasma membrane and that this loss of order then led to the disruption of the myocardial structure and cardiac death.

Another relevant biochemical result demonstrating the importance of Pkp2 in the cardiomyocyte CJs was the finding that the myocardium-specific plaque protein $\alpha$-T-catenin binds to Pkp2 and that this interaction is essential for both the correct topology and function of these proteins in the CJs as well as for the functions of connexin-43 (Cx43) in the adjacent gap junctions (Goossens et al. 2007; Li et al. 2011; for functional interdependence of Pkp2 and Cx43, see also Fidler et al. 2008; Oxford et al. 2007a, b; Sato et al. 2009).

Striking experimental evidence that Pkp2 is of special importance in the formation and maintenance of the CJs of the forming intercalated disks in peri- and postnatal rodents is also provided by the observations with cultured cardiomyocytes that direct interference with the freshly formed and just forming junction structures by siRNAs using PkpmRNA sequences results in the splitting and cleavage of these junctions along their "midplane", followed by the dissociation of the then uncoupled cardiomyocytes and the dispersion of the junctional components over the cytoplasm (Fidler et al. 2008; Hall et al. 2009; Oxford et al. 2007a, b; Pieperhoff et al. 2008). In view of these experimental findings, it now appears less surprising that Pkp2 has also been identified as the by far most frequent and sensitive mutation target resulting in situations of cardiac damage and even sudden death of the arrhythmogenic ventricular cardiomyopathy/ dysplasia (ARVC/D) type (Table 2; for references, see also Calkins 2006, 2011; Cox et al. 2010; Delmar and McKenna 2010; Li and Radice 2010; MacRae et al. 2006; Marcus et al. 2007; Pieperhoff et al. 2010; Sen-Chowdhry et al. 2007).

By contrast, our insight into the nuclear Pkp2 complexes and structures formed and the functions served by nuclear
Table 2 Cardiological publications presenting examples for the important role of plakophilin-2 in the development of arrhythmogenic ventricular cardiomyopathies (ARVC), including "sudden death"

For recent reviews and anthologies, see also: Azaouagh et al. 2011; Delmar and McKenna 2010; Herren et al. 2009; Marcus et al. 2007; Pieperhoff et al. 2010.

\begin{tabular}{lll}
\hline Gerull et al. 2004 & Lahtinen et al. 2008 & Fressart et al. 2010 \\
Antoniades et al. 2006 & Ram and van Wagoner 2008 & van der Zwaag et al. 2010 \\
Awad et al. 2006 & Tandri et al. 2008 & Xu et al. 2010 \\
Basso et al. 2006 & Yu et al. 2008 & Aneq et al. 2011 \\
Calkins 2006 & Bhuiyan et al. 2009 & Basso 2011 \\
Dalal et al. 2006 & den Haan et al. 2009 & Calkins 2011 \\
Kannankeril et al. 2006 & Hall et al. 2009 & Gandjbakhch et al. 2011 \\
Nagaoka et al. 2006 & Qiu et al. 2009 & Lahtinen et al. 2011 \\
Syrris et al. 2006 & Watkins et al. 2009 & Li et al. 2011 \\
Tsatsopoulou et al. 2006 & Wu et al. 2009 & Lombardi and Marian 2011 \\
van Tintelen et al. 2006 & Barahona-Dussault et al. 2010 & Paul et al. 2011 \\
Otterspoor et al. 2007 & Bauce et al. 2010 & Rickelt et al. 2011b \\
Sen-Chowdhry et al. 2007 & Christensen et al. 2010a & van Tintelen 2011 \\
Fidler et al. 2008 & Christensen et al. 2010b & \\
Joshi-Mukherjee et al. 2008 & Cox et al. 2010 & \\
\hline
\end{tabular}


Pkp2 is still very limited. So far, only an RNA polymerase III complex obviously of regulatory importance has been isolated and characterized (Mertens et al. 2001) and Mueller et al. (2003) have reported nuclear Pkp2 phosphorylation in a specific way, followed by complexing with the 14-3-3 protein. Obviously, the nucleoplasm contains several further Pkp2-containing complexes (Mertens et al. 2001) and the intense and specific binding of the antibodies (Abs) to nucleoplasmic structures (see, e.g., Figs. 3, 4, 5 and 7) may now help in isolating such particles and in the elucidation of the nature, reactions and functions of the various nuclear Pkp2 forms. Here, it will be also of experimental help to use junction-free cell lines that only contain nuclear Pkp2 forms such as the murine L929 fibroblastoidal cells (Fig. 7c-c"'). And the armamentarium of the new Pkp2 Abs will also help to decide which isoforms or posttranslational modifications exist in exchange equilibria between nucleoplasm, cytoplasm and junctional plaques and what principles regulate the differential topology of the different Pkp molecules.

And, finally, the set of novel Pkp2 Abs presented here should also contribute to progress in physiologies, pathology and regenerative medicine. For example, the constitutive presence of Pkp2 in non-desmosomal adherens junctions (AJs) connecting certain kinds of mesenchymal or mesenchymally-derived cells of embryonal and fetal mammalian tissues, as well as the demonstrated rapid and stable integration of new Pkp2 molecules in the non-desmosomal junctions connecting mesenchymal or mesenchymallyderived cells, seem to allow the growing and proliferation of such cells in culture, a situation that can quickly return to Pkp2-devoid AJs upon reimplantation of these cells into the natural habitat (for details, see Barth 2011; Barth et al. 2009, 2011). It is also safe to predict that Pkp2 will soon play an increasingly important role in diagnostic pathology, in particular in the diagnoses of non-epithelial tumors, including cardiac and non-cardiac myxomata.

Acknowledgements Some parts of the present report are from my $\mathrm{PhD}$ thesis. I thank my supervisor Werner Franke for critical comments and many discussions. The author also thanks Hans Heid (Helmholtz Group for Cell Biology, German Cancer Research Center, Heidelberg, Germany) for help in database searches, Hanswalter Zentgraf and colleagues (Monoclonal Antibody Facility, German Cancer Research Center) for their help in the generation of the Pkp2 mAbs described and Mareike Barth (Institute for Pharmacology and Clinical Pharmacology / Department of Cardiovascular Surgery - Experimental Surgery, University Hospital Duesseldorf, Duesseldorf, Germany) as well as Stefania Rizzo, Christina Basso and Gaetano Thiene (Department of MedicalDiagnostic Sciences and Department of Cardiac, Thoracic and Vascular Sciences, University of Padova Medical School, Padova, Italy) for many helpful discussions. The work has been supported in parts by the German Cancer Foundation (Deutsche Krebshilfe, grants: 10-2049-Fr1 and 106976 to WWF) and the Federal Ministry for Research and Technology (START-MSC; grant: 01GN0942).
Open Access This article is distributed under the terms of the Creative Commons Attribution Noncommercial License, which permits any noncommercial use, distribution and reproduction in any medium, provided the original author(s) and source are credited.

\section{References}

Aigner K, Descovich L, Mikula M, Sultan A, Dampier B, Bonne S, van Roy F, Mikulits W, Schreiber M, Brabletz T, Sommergruber W, Schweifer N, Wernitznig A, Beug H, Foisner R, Eger A (2007) The transcription factor ZEB1 (deltaEF1) represses Plakophilin 3 during human cancer progression. FEBS Lett 581:1617-1624

Akat K, Mennel HD, Kremer P, Gassler N, Bleck CK, Kartenbeck J (2003) Molecular characterization of desmosomes in meningiomas and arachnoidal tissue. Acta Neuropathol 106:337-347

Akat K, Bleck CK, Lee YM, Haselmann-Weiss U, Kartenbeck J (2008) Characterization of a novel type of adherens junction in meningiomas and the derived cell line HBL-52. Cell Tissue Res 331:401-412

Aneq MA, Fluur C, Lindvall G, Rehnberg M, Soderkvist P, Engvall J, Nylander E, Gunnarsson C (2011) Novel plakophilin2 mutation. Three generation family with arrhythmogenic right ventricular cardiomyopathy. Scand Cardiovasc J, Epub ahead of print

Antoniades L, Tsatsopoulou A, Anastasakis A, Syrris P, Asimaki A, Panagiotakos D, Zambartas C, Stefanadis C, McKenna WJ, Protonotarios N (2006) Arrhythmogenic right ventricular cardiomyopathy caused by deletions in plakophilin-2 and plakoglobin (Naxos disease) in families from Greece and Cyprus: genotype-phenotype relations, diagnostic features and prognosis. Eur Heart J 27:2208-2216

Awad MM, Dalal D, Cho E, Amat-Alarcon N, James C, Tichnell C, Tucker A, Russell SD, Bluemke DA, Dietz HC, Calkins H, Judge DP (2006) DSG2 mutations contribute to arrhythmogenic right ventricular dysplasia/cardiomyopathy. Am J Hum Genet 79:136-142

Azaouagh A, Churzidse S, Konorza T, Erbel R (2011) Arrhythmogenic right ventricular cardiomyopathy/dysplasia: a review and update. Clin Res Cardiol 100:383-394

Barahona-Dussault C, Benito B, Campuzano O, Iglesias A, Leung TL, Robb L, Talajic M, Brugada R (2010) Role of genetic testing in arrhythmogenic right ventricular cardiomyopathy/dysplasia. Clin Genet 77:37-48

Barth M (2011) The cell and molecular biological characterization of cell-cell junctions in mammalian heart valves. Thesis, University of Heidelberg, Heidelberg

Barth M, Schumacher H, Kuhn C, Akhyari P, Lichtenberg A, Franke WW (2009) Cordial connections: molecular ensembles and structures of adhering junctions connecting interstitial cells of cardiac valves in situ and in cell culture. Cell Tissue Res 337:63-77

Barth M, Akhyari P, Lichtenberg A, Franke WW (2011) The adhering junctions of mammalian valvular interstitial cells - Characterization of fetal and adult heart valves in situ and in culture. Cell Tiss Res (in press)

Basso C (2011) The changing spectrum of arrhythmogenic cardiomyopathy. Cell Tiss Res (in press)

Basso C, Czarnowska E, Barbera MD, Bauce B, Beffagna G, Wlodarska EK, Pilichou K, Ramondo A, Lorenzon A, Wozniek O, Corrado D, Daliento L, Danieli GA, Valente M, Nava A, Thiene G, Rampazzo A (2006) Ultrastructural evidence of intercalated disc remodelling in arrhythmogenic right ventricular cardiomyopathy: an electron microscopy investigation on endomyocardial biopsies. Eur Heart J 27:1847-1854

Bass-Zubek AE, Hobbs RP, Amargo EV, Garcia NJ, Hsieh SN, Chen X, Wahl JK 3rd, Denning MF, Green KJ (2008) Plakophilin 2: a critical scaffold for PKC alpha that regulates intercellular junction assembly. J Cell Biol 181:605-613 
Bass-Zubek AE, Godsel LM, Delmar M, Green KJ (2009) Plakophilins: multifunctional scaffolds for adhesion and signaling. Curr Opin Cell Biol 21:708-716

Bauce B, Nava A, Beffagna G, Basso C, Lorenzon A, Smaniotto G, De Bortoli M, Rigato I, Mazzotti E, Steriotis A, Marra MP, Towbin JA, Thiene G, Danieli GA, Rampazzo A (2010) Multiple mutations in desmosomal proteins encoding genes in arrhythmogenic right ventricular cardiomyopathy/dysplasia. Heart Rhythm 7:22-29

Bhuiyan ZA, Jongbloed JD, van der Smagt J, Lombardi PM, Wiesfeld AC, Nelen M, Schouten M, Jongbloed R, Cox MG, van Wolferen M, Rodriguez LM, van Gelder IC, Bikker H, Suurmeijer AJ, van den Berg MP, Mannens MM, Hauer RN, Wilde AA, van Tintelen JP (2009) Desmoglein-2 and desmocollin-2 mutations in dutch arrhythmogenic right ventricular dysplasia/cardiomypathy patients: results from a multicenter study. Circ Cardiovasc Genet 2:418-427

Bonné S, van Hengel J, Nollet F, Kools P, van Roy F (1999) Plakophilin3 , a novel armadillo-like protein present in nuclei and desmosomes of epithelial cells. J Cell Sci 112:2265-2276

Bonné S, van Hengel J, van Roy F (2000) Assignment of the plakophilin2 gene (PKP2) and a plakophilin-2 pseudogene (PKP2P1) to human chromosome bands $12 \mathrm{p} 11$ and $12 \mathrm{p} 13$, respectively, by in situ hybridization. Cytogenet Cell Genet 88:286-287

Bonné S, Gilbert B, Hatzfeld M, Chen X, Green KJ, van Roy F (2003) Defining desmosomal plakophilin-3 interactions. J Cell Biol 161:403-416

Borrmann CM (2000) Molekulare Charakterisierung der AdhaerensZellverbindungen des Herzens: Identifizierung einer neuen Art, der Area Composita. Thesis, University of Heidelberg, Heidelberg

Borrmann CM, Mertens C, Schmidt A, Langbein L, Kuhn C, Franke WW (2000) Molecular diversity of plaques of epithelial adhering junctions. Ann N Y Acad Sci 915:144-150

Borrmann CM, Grund C, Kuhn C, Hofmann I, Pieperhoff S, Franke WW (2006) The area composita of adhering junctions connecting heart muscle cells of vertebrates. II. Colocalizations of desmosomal and fascia adhaerens molecules in the intercalated disk. Eur J Cell Biol 85:469-485

Calkins HM (2006) Arrhythmogenic right-ventricular dysplasia/ cardiomyopathy. Curr Opin Cardiol 21:55-63

Calkins HM (2011) Clinical challenges in ARVC/D: A United States perspective. Cell Tiss Res, (in press)

Christensen AH, Benn M, Bundgaard H, Tybjaerg-Hansen A, Haunso S, Svendsen JH (2010a) Wide spectrum of desmosomal mutations in Danish patients with arrhythmogenic right ventricular cardiomyopathy. J Med Genet 47:736-744

Christensen AH, Benn M, Tybjaerg-Hansen A, Haunso S, Svendsen JH (2010b) Missense variants in plakophilin-2 in arrhythmogenic right ventricular cardiomyopathy patients-disease-causing or innocent bystanders? Cardiology 115:148-154

Claycomb WC, Lanson NA Jr, Stallworth BS, Egeland DB, Delcarpio JB, Bahinski A, Izzo NJ Jr (1998) HL-1 cells: a cardiac muscle cell line that contracts and retains phenotypic characteristics of the adult cardiomyocyte. Proc Natl Acad Sci USA 95:2979-2984

Cox MG, van der Smagt JJ, Noorman M, Wiesfeld AC, Volders PG, van Langen IM, Atsma DE, Dooijes D, Houweling AC, Loh P, Jordaens L, Arens Y, Cramer MJ, Doevendans PA, van Tintelen JP, Wilde AA, Hauer RN (2010) Arrhythmogenic right ventricular dysplasia/cardiomyopathy diagnostic task force criteria: impact of new task force criteria. Circ Arrhythm Electrophysiol 3:126-133

Dalal D, Molin LH, Piccini J, Tichnell C, James C, Bomma C, Prakasa K, Towbin JA, Marcus FI, Spevak PJ, Bluemke DA, Abraham T, Russell SD, Calkins H, Judge DP (2006) Clinical features of arrhythmogenic right ventricular dysplasia/cardiomyopathy associated with mutations in plakophilin-2. Circulation 113:16411649
Delmar M, McKenna WJ (2010) The cardiac desmosome and arrhythmogenic cardiomyopathies: from gene to disease. Circ Res 107:700-714

Delva E, Tucker DK, Kowalczyk AP (2010) The desmosome. In: Nelson J, Fuchs E (eds) Cold Spring Harbor Perspectives in Biology. Cell-Cell Junctions, vol. 1. Cold Spring Harbor Laboratory Press, New York, pp 83-99

den Haan AD, Tan BY, Zikusoka MN, Llado LI, Jain R, Daly A, Tichnell C, James C, Amat-Alarcon N, Abraham T, Russell SD, Bluemke DA, Calkins H, Dalal D, Judge DP (2009) Comprehensive desmosome mutation analysis in North Americans with arrhythmogenic right ventricular dysplasia/cardiomyopathy. Circ Cardiovasc Genet 2:428-435

Fidler LM, Wilson GJ, Liu F, Cui X, Scherer SW, Taylor GP, Hamilton RM (2008) Abnormal connexin43 in arrhythmogenic right ventricular cardiomyopathy caused by plakophilin- 2 mutations. J Cell Mol Med 13:4219-4228

Folpe AL, Gown A (2001) Immunohistochemistry for analysis of soft tissue tumors. In: Weiss S, Goldblum J (eds) Soft tissue tumors, vol 4. Mosby, St. Louis, pp 199-245

Franke WW (2010) Discovering the molecular components of intercellular junctions - a historical view. In: Nelson J, Fuchs E (eds) Cold Spring Harbor Perspectives in Biology. Cell-Cell Junctions, vol. 1. Cold Spring Harbor Laboratory Press, New York, pp 1-34

Franke WW, Rickelt S (2011) Mesenchymal-epithelial transitions: Spontaneous and cumulative syntheses of epithelial marker molecules and their assemblies to novel cell junctions connecting human hematopoietic tumor cells to carcinomatoid tissue structures. Int J Cancer 129:2588-2599

Franke WW, Moll R, Mueller H, Schmid E, Kuhn C, Krepler R, Artlieb U, Denk H (1983) Immunocytochemical identification of epithelium-derived human tumors with antibodies to desmosomal plaque proteins. Proc Natl Acad Sci USA 80:543-547

Franke WW, Borrmann CM, Grund C, Pieperhoff S (2006) The area composita of adhering junctions connecting heart muscle cells of vertebrates. I. Molecular definition in intercalated disks of cardiomyocytes by immunoelectron microscopy of desmosomal proteins. Eur J Cell Biol 85:69-82

Fressart V, Duthoit G, Donal E, Probst V, Deharo JC, Chevalier P, Klug D, Dubourg O, Delacretaz E, Cosnay P, Scanu P, Extramiana F, Keller D, Hidden-Lucet F, Simon F, Bessirard V, Roux-Buisson N, Hebert JL, Azarine A, Casset-Senon D, Rouzet F, Lecarpentier Y, Fontaine G, Coirault C, Frank R, Hainque B, Charron P (2010) Desmosomal gene analysis in arrhythmogenic right ventricular dysplasia/cardiomyopathy: spectrum of mutations and clinical impact in practice. Europace 12:861-868

Furukawa C, Daigo Y, Ishikawa N, Kato T, Ito T, Tsuchiya E, Sone S, Nakamura Y (2005) Plakophilin 3 oncogene as prognostic marker and therapeutic target for lung cancer. Cancer Res 65:7102-7110

Gandjbakhch E, Charron P, Fressart V, Lorin de la Grandmaison G, Simon F, Gary F, Vite A, Hainque B, Hidden-Lucet F, Komajda M, Villard E (2011) Plakophilin 2A is the dominant isoform in human heart tissue: consequences for the genetic screening of arrhythmogenic right ventricular cardiomyopathy. Heart 97:844-849

Garrod D, Chidgey M, North A (1996) Desmosomes: differentiation, development, dynamics and disease. Curr Opin Cell Biol 8:670-678

Gerull B, Heuser A, Wichter T, Paul M, Basson CT, McDermott DA, Lerman BB, Markowitz SM, Ellinor PT, MacRae CA, Peters S, Grossmann KS, Drenckhahn J, Michely B, Sasse-Klaassen S, Birchmeier W, Dietz R, Breithardt G, Schulze-Bahr E, Thierfelder L (2004) Mutations in the desmosomal protein plakophilin-2 are common in arrhythmogenic right ventricular cardiomyopathy. Nat Genet 36:1162-1164

Godsel LM, Getsios S, Huen AC, Green KJ (2004) The molecular composition and function of desmosomes. In: Behrens J, Nelson 
WJ (eds) Cell Adhesion, vol. 165. Handbook of Experimental Pharmacology. Springer, Berlin, pp 137-193

Goossens S, Janssens B, Bonne S, De Rycke R, Braet F, van Hengel J, van Roy F (2007) A unique and specific interaction between alphaT-catenin and plakophilin-2 in the area composita, the mixed-type junctional structure of cardiac intercalated discs. J Cell Sci 120:2126-2136

Gown AM, Vogel AM (1984) Distribution of filament proteins in normal human tissues. Monoclonal antibodies to human intermediate filament proteins. Am J Pathol 114:309-321

Green KJ, Getsios S, Troyanovsky S, Godsel LM (2010) Intercellular junction assembly, dynamics, and homeostasis. In: Nelson J, Fuchs E (eds) Cold Spring Harbor Perspectives in Biology. CellCell Junctions., vol 1. Cold Spring Harbor Laboratory Press, New York, pp 157-178

Grossmann KS (2005) Bedeutung von Plakophilin 2 fuer die Bildung von Zellverbindungen zwischen Herzmuskelzellen und die Morphogenese des Herzens. Thesis, Humboldt-University of Berlin, Berlin

Grossmann KS, Grund C, Huelsken J, Behrend M, Erdmann B, Franke WW, Birchmeier W (2004) Requirement of plakophilin 2 for heart morphogenesis and cardiac junction formation. J Cell Biol 167:149-160

Hall C, Li S, Li H, Creason V, Wahl JK 3rd (2009) Arrhythmogenic right ventricular cardiomyopathy plakophilin-2 mutations disrupt desmosome assembly and stability. Cell Commun Adhes 16:15-27

Hatzfeld M (2007) Plakophilins: Multifunctional proteins or just regulators of desmosomal adhesion? Biochim Biophys Acta 1773:69-77

Hatzfeld M, Kristjansson GI, Plessmann U, Weber K (1994) Band 6 protein, a major constituent of desmosomes from stratified epithelia, is a novel member of the armadillo multigene family. J Cell Sci 107:2259-2270

Heid HW, Schmidt A, Zimbelmann R, Schaefer S, Winter-Simanowski S, Stumpp S, Keith M, Figge U, Schnoelzer M, Franke WW (1994) Cell type-specific desmosomal plaque proteins of the plakoglobin family: plakophilin 1 (band 6 protein). Differentiation 58:113-131

Herren T, Gerber PA, Duru F (2009) Arrhythmogenic right ventricular cardiomyopathy/dysplasia: a not so rare "disease of the desmosome" with multiple clinical presentations. Clin Res Cardiol 98:141-158

Hofmann I, Casella M, Schnoelzer M, Schlechter T, Spring H, Franke WW (2006) Identification of the junctional plaque protein plakophilin 3 in cytoplasmic particles containing RNA-binding proteins and the recruitment of plakophilins 1 and 3 to stress granules. Mol Biol Cell 17:1388-1398

Joshi-Mukherjee R, Coombs W, Musa H, Oxford E, Taffet S, Delmar M (2008) Characterization of the molecular phenotype of two arrhythmogenic right ventricular cardiomyopathy (ARVC)-related plakophilin-2 (PKP2) mutations. Heart Rhythm 5:1715-1723

Kannankeril PJ, Bhuiyan ZA, Darbar D, Mannens MM, Wilde AA, Roden DM (2006) Arrhythmogenic right ventricular cardiomyopathy due to a novel plakophilin 2 mutation: wide spectrum of disease in mutation carriers within a family. Heart Rhythm 3:939-944

Koeser J, Troyanovsky SM, Grund C, Franke WW (2003) De novo formation of desmosomes in cultured cells upon transfection of genes encoding specific desmosomal components. Exp Cell Res 285:114-130

Kundu ST, Gosavi P, Khapare N, Patel R, Hosing AS, Maru GB, Ingle A, Decaprio JA, Dalal SN (2008) Plakophilin3 downregulation leads to a decrease in cell adhesion and promotes metastasis. Int $\mathrm{J}$ Cancer 123:2303-2314

Lahtinen AM, Lehtonen A, Kaartinen M, Toivonen L, Swan H, Widen E, Lehtonen E, Lehto VP, Kontula K (2008) Plakophilin-2 missense mutations in arrhythmogenic right ventricular cardiomyopathy. Int J Cardiol 126:92-100

Lahtinen AM, Lehtonen E, Marjamaa A, Kaartinen M, Helio T, Porthan K, Oikarinen L, Toivonen L, Swan H, Jula A, Peltonen L, Palotie A, Salomaa V, Kontula K (2011) Population-prevalent desmosomal mutations predisposing to arrhythmogenic right ventricular cardiomyopathy. Heart Rhythm 8:1214-1221

Li J, Radice GL (2010) A new perspective on intercalated disc organization: implications for heart disease. In: Mohoney G, Mueller EJ, Koch PJ (eds) Dermatology Research and Practice. Desmosomes and desmosomal cadherin function in skin and heart diseases Advancements in basic and clinical research. Hindawi, LaVergne, Article ID 207835

Li J, Swope D, Cheng L, Gao E, Raess N, Mueller EJ, van Hengel J, van Roy F, Radice GL (2011) Catenins: Multi-function proteins involved in cell adhesion, communication, and signaling in the heart. Cell Tiss Res (in press)

Lombardi R, Marian AJ (2011) Molecular genetics and pathogenesis of arrhythmogenic right ventricular cardiomyopathy: a disease of cardiac stem cells. Pediatr Cardiol 32:360-365

MacRae CA, Birchmeier W, Thierfelder L (2006) Arrhythmogenic right ventricular cardiomyopathy: moving toward mechanism. J Clin Invest 116:1825-1828

Marcus FI, Nava A, Thiene G (2007) Arrhythmogenic RV Cardiomyopathy/Dysplasia Recent Advances. Springer, Milan

McAllister HA, Fenoglio JJ (1978) Tumors of the Cardiovascular System. AFIP, Washington, D.C

Mertens C, Kuhn C, Franke WW (1996) Plakophilins 2a and 2b: constitutive proteins of dual location in the karyoplasm and the desmosomal plaque. J Cell Biol 135:1009-1025

Mertens C, Kuhn C, Moll R, Schwetlick I, Franke WW (1999) Desmosomal plakophilin 2 as a differentiation marker in normal and malignant tissues. Differentiation 64:277-290

Mertens C, Hofmann I, Wang Z, Teichmann M, Sepehri Chong S, Schnoelzer M, Franke WW (2001) Nuclear particles containing RNA polymerase III complexes associated with the junctional plaque protein plakophilin 2. Proc Natl Acad Sci USA 98:7795-7800

Miettinen M (2003) Diagnostic Soft Tissue Pathology. Churchill Livingstone, New York

Moll R (1993) Cytokeratine als Differenzierungsmarker: Expressionsprofile von Epithelien und epithelialen Tumoren. Gustav Fischer, Stuttgart

Moll R, Cowin P, Kapprell HP, Franke WW (1986) Desmosomal proteins: new markers for identification and classification of tumors. Lab Invest 54:4-25

Moll I, Kurzen H, Langbein L, Franke WW (1997) The distribution of the desmosomal protein, plakophilin 1 , in human skin and skin tumors. J Invest Dermatol 108:139-146

Moll R, Holzhausen HJ, Mennel HD, Kuhn C, Baumann R, Taege C, Franke WW (2006) The cardiac isoform of alpha-actin in regenerating and atrophic skeletal muscle, myopathies and rhabdomyomatous tumors: an immunohistochemical study using monoclonal antibodies. Virchows Arch 449:175-191

Mueller J, Ritt DA, Copeland TD, Morrison DK (2003) Functional analysis of C-TAK1 substrate binding and identification of PKP2 as a new C-TAK1 substrate. EMBO J 22:4431-4442

Nagaoka I, Matsui K, Ueyama T, Kanemoto M, Wu J, Shimizu A, Matsuzaki M, Horie M (2006) Novel mutation of plakophilin-2 associated with arrhythmogenic right ventricular cardiomyopathy. Circ J 70:933-935

Neuber S, Muehmer M, Wratten D, Koch PJ, Moll R, Schmidt A (2010) The desmosomal plaque proteins of the plakophilin family. In: Mohoney G, Mueller EJ, Koch PJ (eds) Dermatology Research and Practice. Desmosomes and desmosomal cadherin function in skin and heart diseases - Advancements in basic and clinical research. Hindawi, LaVergne, Article ID 101452 
North AJ, Bardsley WG, Hyam J, Bornslaeger EA, Cordingley HC, Trinnaman B, Hatzfeld M, Green KJ, Magee AI, Garrod DR (1999) Molecular map of the desmosomal plaque. J Cell Sci 112:4325-4336

Otterspoor LC, Reichert CL, Cramer MJ, Bhuiyan ZA, Wilde AA, Hauer RN (2007) Arrhythmogenic right ventricular cardiomyopathy: asymptomatic to life threatening as illustrated by the cases of two sisters. Neth Heart J 15:348-353

Oxford EM, Everitt M, Coombs W, Fox PR, Kraus M, Gelzer AR, Saffitz J, Taffet SM, Moise NS, Delmar M (2007a) Molecular composition of the intercalated disc in a spontaneous canine animal model of arrhythmogenic right ventricular dysplasia/ cardiomyopathy. Heart Rhythm 4:1196-1205

Oxford EM, Musa H, Maass K, Coombs W, Taffet SM, Delmar M (2007b) Connexin43 remodeling caused by inhibition of plakophilin-2 expression in cardiac cells. Circ Res 101:703-711

Papagerakis S, Shabana AH, Depondt J, Gehanno P, Forest N (2003) Immunohistochemical localization of plakophilins (PKP1, PKP2, PKP3, and p0071) in primary oropharyngeal tumors: correlation with clinical parameters. Hum Pathol 34:565-572

Parrish EP, Garrod DR, Mattey DL, Hand L, Steart PV, Weller RO (1986) Mouse antisera specific for desmosomal adhesion molecules of suprabasal skin cells, meninges, and meningioma. Proc Natl Acad Sci USA 83:2657-2661

Paul M, Wichter T, Kies P, Gerss J, Wollmann C, Rahbar K, Eckardt L, Breithardt G, Schober O, Schulze-Bahr E, Schafers M (2011) Cardiac sympathetic dysfunction in genotyped patients with arrhythmogenic right ventricular cardiomyopathy and risk of recurrent ventricular tachyarrhythmias. J Nucl Med 52:1559-1565

Pieperhoff S, Franke WW (2007) The area composita of adhering junctions connecting heart muscle cells of vertebrates - IV: Coalescence and amalgamation of desmosomal and adhaerens junction components - late processes in mammalian heart development. Eur J Cell Biol 86:377-391

Pieperhoff S, Schumacher H, Franke WW (2008) The area composita of adhering junctions connecting heart muscle cells of vertebrates. V. The importance of plakophilin-2 demonstrated by small interference RNA-mediated knockdown in cultured rat cardiomyocytes. Eur J Cell Biol 87:399-411

Pieperhoff S, Barth M, Rickelt S, Franke WW (2010) Desmosomal molecules in and out of adhering junctions: normal and diseased states of epidermal, cardiac and mesenchymally derived cells. In: Mohoney G, Mueller EJ, Koch PJ (eds) Dermatology Research and Practice. Desmosomes and desmosomal cadherin function in skin and heart diseases - Advancements in basic and clinical research. Hindawi, LaVergne, Article ID 139167

Pieperhoff S, Rickelt S, Heid H, Claycomb WC, Zimbelmann R, Kuhn C, Winter-Simanowski S, Frey N, Franke WW (2011) The plaque protein myozap identified as a novel major component of adhering junctions in endothelia of the blood and the lymph vascular systems. J Cell Mol Med, Epub ahead of print

Qiu X, Liu W, Hu D, Zhu T, Li C, Li L, Guo C, Liu X, Wang L, Zheng H, Wang C, Diao Q, Shi D, Zhan P, Deng Y, Liu K, Wang Y, Liu B, Liu H, Zhang L (2009) Mutations of plakophilin-2 in Chinese with arrhythmogenic right ventricular dysplasia/cardiomyopathy. Am J Cardiol 103:1439-1444

Ram R, van Wagoner DR (2008) Plakophilin-2 mutations as a cause of arrhythmogenic right ventricular cardiomyopathy: progress toward linking structural with functional changes. Heart Rhythm 5:1724-1725

Rickelt S (2010) The molecular and cell biological characterization of cell-cell junctions in mesenchymally derived cells and tissues. Thesis, University of Heidelberg, Heidelberg

Rickelt S, Winter-Simanowski S, Noffz E, Kuhn C, Franke WW (2009) Upregulation of plakophilin-2 and its acquisition to adherens junctions identifies a novel molecular ensemble of cell-cell- attachment characteristic for transformed mesenchymal cells. Int $\mathrm{J}$ Cancer 125:2036-2048

Rickelt S, Rizzo S, Doerflinger Y, Zentgraf H, Basso C, Gerosa G, Thiene G, Moll R, Franke WW (2010) A novel kind of tumor type-characteristic junction: plakophilin-2 as a major protein of adherens junctions in cardiac myxomata. Mod Pathol 23:1429-1437

Rickelt S, Moll I, Franke WW (2011a) Intercellular adhering junctions with an asymmetric molecular composition: desmosomes connecting Merkel cells and keratinocytes. Cell Tissue Res 346:65-77

Rickelt S, Rizzo S, Barth M, Franke WW (2011b) The specific molecular ensembles of the junctions connecting mesenchymally-derived tumor cells, including cardiac myxomata: the coming and going of plakophilin-2. Cell Tiss Res (in press)

Sato PY, Musa H, Coombs W, Guerrero-Serna G, Patino GA, Taffet SM, Isom LL, Delmar M (2009) Loss of plakophilin-2 expression leads to decreased sodium current and slower conduction velocity in cultured cardiac myocytes. Circ Res 105:523-526

Schaefer S, Troyanovsky SM, Heid HW, Eshkind LG, Koch PJ, Franke WW (1993) Cytoskeletal architecture and epithelial differentiation: molecular determinants of cell interaction and cytoskeletal filament anchorage. C R Acad Sci III 316:1316-1323

Schmidt A, Jaeger S (2005) Plakophilins: hard work in the desmosome, recreation in the nucleus? Eur J Cell Biol 84:189-204

Schmidt A, Koch PJ (2008) Desmosomes in development and disease. In: La Flamme SE, Kowalczyk AP (eds) Cell Junctions. Wiley, Weinheim, pp 235-249

Schmidt A, Heid HW, Schaefer S, Nuber UA, Zimbelmann R, Franke WW (1994) Desmosomes and cytoskeletal architecture in epithelial differentiation: cell type-specific plaque components and intermediate filament anchorage. Eur J Cell Biol 65:229-245

Schmidt A, Langbein L, Rode M, Praetzel S, Zimbelmann R, Franke WW (1997) Plakophilins 1a and 1b: widespread nuclear proteins recruited in specific epithelial cells as desmosomal plaque components. Cell Tissue Res 290:481-499

Schmidt A, Langbein L, Praetzel S, Rode M, Rackwitz HR, Franke WW (1999) Plakophilin 3 - a novel cell-type-specific desmosomal plaque protein. Differentiation 64:291-306

Schwarz J, Ayim A, Schmidt A, Jager S, Koch S, Baumann R, Dunne AA, Moll R (2006) Differential expression of desmosomal plakophilins in various types of carcinomas: correlation with cell type and differentiation. Hum Pathol 37:613-622

Sen-Chowdhry S, Syrris P, Ward D, Asimaki A, Sevdalis E, McKenna WJ (2007) Clinical and genetic characterization of families with arrhythmogenic right ventricular dysplasia/cardiomyopathy provides novel insights into patterns of disease expression. Circulation 115:1710-1720

Sheppard MN (2011) Practical Cardiovascular Pathology. Hodder Arnold, London

Shi SR, Gu G, Taylor CR (2000) Antigen Retrieval Techniques: Immunohistochemistry and Molecular Morphology. Eaton, Natick

Sobolik-Delmaire T, Katafiasz D, Keim SA, Mahoney MG, Wahl JK 3rd (2007) Decreased plakophilin-1 expression promotes increased motility in head and neck squamous cell carcinoma cells. Cell Commun Adhes 14:99-109

South AP, Wan H, Stone MG, Dopping-Hepenstal PJ, Purkis PE, Marshall JF, Leigh IM, Eady RA, Hart IR, McGrath JA (2003) Lack of plakophilin 1 increases keratinocyte migration and reduces desmosome stability. J Cell Sci 116:3303-3314

Syrris P, Ward D, Asimaki A, Sen-Chowdhry S, Ebrahim HY, Evans A, Hitomi N, Norman M, Pantazis A, Shaw AL, Elliott PM, McKenna WJ (2006) Clinical expression of plakophilin-2 mutations in familial arrhythmogenic right ventricular cardiomyopathy. Circulation 113:356-364 
Tandri H, Asimaki A, Dalal D, Saffitz JE, Halushka MK, Calkins H (2008) Gap junction remodeling in a case of arrhythmogenic right ventricular dysplasia due to plakophilin-2 mutation. J Cardiovasc Electrophysiol 19:1212-1214

Travis WD, Brambilla E, Mueller-Hermelink HK, Harris CC (2004) World Health Organization Classification of Tumours. Pathology and Genetics of Tumours of the Lung, Pleura, Thymus and Heart. IARC, Lyon

Tsatsopoulou AA, Protonotarios NI, McKenna WJ (2006) Arrhythmogenic right ventricular dysplasia, a cell adhesion cardiomyopathy: insights into disease pathogenesis from preliminary genotype-phenotype assessment. Heart 92:1720-1723

van der Zwaag PA, Cox MG, van der Werf C, Wiesfeld AC, Jongbloed JD, Dooijes D, Bikker H, Jongbloed R, Suurmeijer AJ, van den Berg MP, Hofstra RM, Hauer RN, Wilde AA, van Tintelen JP (2010) Recurrent and founder mutations in the Netherlands: Plakophilin-2 p.Arg79X mutation causing arrhythmogenic right ventricular cardiomyopathy/dysplasia. Neth Heart J 18:583-591

van Tintelen JP (2011) Arrhythmogenic right ventricular cardiomyopathy; a clinical and genetic perspective on desmosomes, desmin and calcium. Cell Tiss Res (in press)

van Tintelen JP, Entius MM, Bhuiyan ZA, Jongbloed R, Wiesfeld AC, Wilde AA, van der Smagt J, Boven LG, Mannens MM, van Langen IM, Hofstra RM, Otterspoor LC, Doevendans PA, Rodriguez LM, van Gelder IC, Hauer RN (2006) Plakophilin-2 mutations are the major determinant of familial arrhythmogenic right ventricular dysplasia/cardiomyopathy. Circulation 113:1650-1658

Watkins DA, Hendricks N, Shaboodien G, Mbele M, Parker M, Vezi BZ, Latib A, Chin A, Little F, Badri M, Moolman-Smook JC, Okreglicki A, Mayosi BM (2009) Clinical features, survival experience, and profile of plakophylin-2 gene mutations in participants of the arrhythmogenic right ventricular cardiomyopathy registry of South Africa. Heart Rhythm 6:S10-S17

Wu SL, Wang PN, Hou YS, Zhang XC, Shan ZX, Yu XY, Deng M (2009) Mutation of plakophilin-2 gene in arrhythmogenic right ventricular cardiomyopathy. Chin Med J (Engl) 122:403-407

Wuchter P, Boda-Heggemann J, Straub BK, Grund C, Kuhn C, Krause U, Seckinger A, Peitsch WK, Spring H, Ho AD, Franke WW (2007) Processus and recessus adhaerentes: giant adherens cell junction systems connect and attract human mesenchymal stem cells. Cell Tissue Res 328:499-514

Xu T, Yang Z, Vatta M, Rampazzo A, Beffagna G, Pilichou K, Scherer SE, Saffitz J, Kravitz J, Zareba W, Danieli GA, Lorenzon A, Nava A, Bauce B, Thiene G, Basso C, Calkins H, Gear K, Marcus F, Towbin JA (2010) Compound and digenic heterozygosity contributes to arrhythmogenic right ventricular cardiomyopathy. J Am Coll Cardiol 55:587-597

Yu CC, Yu CH, Hsueh CH, Yang CT, Juang JM, Hwang JJ, Lin JL, Lai LP (2008) Arrhythmogenic right ventricular dysplasia: clinical characteristics and identification of novel desmosome gene mutations. J Formos Med Assoc 107:548-558 